\title{
THYROID SURGERY IN CHILDREN AND ADOLESCENTS: A 10-YEAR RETROSPECTIVE STUDY AT A SINGLE INSTITUTION
}

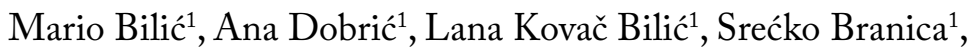 \\ Ika Gugić Radojković ${ }^{1}$, Drago Prgomet ${ }^{1}$ \\ ${ }^{1}$ Department of Otolaryngology, Head and Neck Surgery, Zagreb University Hospital Centre, Zagreb, Croatia
}

\begin{abstract}
SUMMARY - Objective. The aim of the study was to analyze clinical characteristics, surgical treatment, complications, and prognosis related to thyroid surgery in children and adolescents in a $10-$ year study at a single institution. Study Design. Retrospective study. Methods. We performed a retrospective analysis of clinical data of children and adolescents who underwent thyroid surgery due to benign thyroid disease and thyroid cancer from January 2011 to May 2020. We presented the clinical characteristics and type of surgical treatment for different thyroid diseases. Results. We present data on surgical procedures and complication rates following surgery, which was comparable to other published data. We emphasize the importance of radioiodine and hormone replacement postoperative therapy in cancer patients and our opinion on total thyroidectomy and neck dissection in thyroid cancer surgery. Conclusion. This study demonstrated that thyroid surgery in children and adolescents is a safe and efficient procedure in the hands of experienced surgeon for adult thyroid surgery. For children and adolescents with thyroid carcinoma, our method of choice is total thyroidectomy with occasionally paratracheal neck dissection, whereas lateral cervical lymph node dissection is only necessary in fine needle aspiration positive lymph nodes. Our results according to postoperative outcomes and complications are comparable to other recently published data.
\end{abstract}

Key words: thyroidectomy, child, adolescent

\section{Introduction}

As a surgical procedure, thyroidectomy is quite rare in children and is mostly related to thyroid neoplasm. However, there are some benign diseases of the thyroid gland in the pediatric population such as Grave's disease, toxic adenomas, congenital hyperthyroidism, and goiter which also require surgery. ${ }^{1}$ This type of surgery in children can be extremely challenging for surgeons, firstly due to the fact that the surgeon performing thyroid surgery on children will be either a head and neck surgeon experienced in adult thyroid gland surgery or a pediatric surgeon more familiar with pediatric pa-

Correspondence to: Mario Bilic, $M D, P h D$, Department of Otolaryngology, Head and Neck Surgery, Zagreb University Hospital Centre, Kišpatićeva 12, 10000 Zagreb, Croatia

e-mail: mbilic100@gmail.com thology. ${ }^{2,3}$ Whatever type of surgeon is involved in thyroid surgery, their overall experience will be limited as those disease are relatively rare. A multidisciplinary approach that involves a pediatric endocrinologist, pediatricians, nuclear medicine physicians, an anesthesiologist, and a pathologist is a crucial part of preoperative, postoperative, and follow-up management of children with thyroid disease, especially for those children who underwent thyroidectomy. The other problem is that very strict guidelines regarding management for patients with thyroid nodules and differentiated thyroid cancer exist for the adult population, but according to literature they are significantly fewer guidelines for the pediatric population. ${ }^{4}$ These guidelines mostly differ in surgeon volume and indications for total thyreoidectomy. ${ }^{2}$ The incidence of malignant thyroid nodules in children and adolescents is up to 
$25 \%$, with a higher risk at a lower age. ${ }^{5}$ Despite this, the prognosis is good but the modes of treatment of thyroid cancer in children and adolescent are still controversial. Authors mostly debate whether children need to undergo aggressive therapy, including total thyroidectomy and radioactive iodine (RAI) therapy, after initial surgery and whether younger patients are at greater risk for more extensive and recurrent disease. ${ }^{6,7}$ In this study, we reviewed retrospective clinical data from 58 patients aged 6 to 18 years. All patients underwent surgery for different thyroid diseases. We present our results according to indication, effectiveness of our surgical and postoperative approach, and long-term outcome.

\section{Methods}

This study was a retrospective analysis of a total of 58 pediatric patients ( $\leq 18$ years old) who underwent thyroid surgery at the Department of Otorhinolaryngology, Head and Neck Surgery, Zagreb University Hospital Center from January 2011 to May 2020. Patients were aged between 6 to 18 years and divided into two groups according to age: $\leq 12$ and $>12$ years old. The younger group included 15 patients while the older group included 43 patients. The mean age of all patients was 14.4 years, and there were 54 girls and 4 boys.

In all patients, the surgery was performed by experienced head and neck surgeons specializing in thyroid surgery in adult patients but with great knowledge in pediatric otorhinolaryngology., The recurrent laryngeal nerves were routinely monitored preoperatively and postoperatively in all patients. Thyroid ultrasound and ultrasound-guided FNA of a thyroid nodule was performed by pediatric endocrinologists from the Department of Pediatrics, Zagreb University Hospital Center, and all histopathology specimens were examined at the Department of Pathology, Zagreb University Hospital Center. As demographic and preoperative data, we included the number of patients per year, age, mean age, type of surgical procedure, histopathological diagnosis, and complications. We retrospectively analyzed the type of surgery for the different thyroid diseases in children and evaluated whether thyroid surgery in children can be performed with a comparable outcome and morbidity rate as in adults and as reported in recent publications. All data are ex-
Table 1. Number of patients distributed by year of surgery, sex, and mean age

\begin{tabular}{|l|c|c|c|c|}
\hline Year & $\begin{array}{c}\text { Number of } \\
\text { patients }\end{array}$ & $\begin{array}{c}\text { Number } \\
\text { of female } \\
\text { patients }\end{array}$ & $\begin{array}{c}\text { Number } \\
\text { of male } \\
\text { patients }\end{array}$ & Mean age \\
\hline 2011 & 8 & 8 & 0 & 15.5 \\
2012 & 4 & 4 & 0 & 14.7 \\
2013 & 4 & 4 & 0 & 14.5 \\
2014 & 11 & 10 & 1 & 14.0 \\
2015 & 5 & 5 & 0 & 11.8 \\
2016 & 4 & 3 & 1 & 14.7 \\
2017 & 5 & 5 & 0 & 14.4 \\
2018 & 8 & 7 & 1 & 14.7 \\
2019 & 7 & 6 & 1 & 16.4 \\
2020 & 2 & 2 & 0 & 13.5 \\
\hline Total & 58 & 54 & 4 & 14.4 \\
\hline
\end{tabular}

pressed as medians with ranges and were generated with GraphPad Prism Version 5.0.

\section{Results}

From the total of 58 patients, we performed 21 lobectomies, 37 total thyroidectomies, 12 paratracheal neck dissections, 10 selective neck dissections, and 1 sternotomy with partial pleurectomy. Histopathologically, we found 23 multinodular goiters, 9 follicular thyroid adenomas, 25 papillary thyroid cancers, and 1 medullary thyroid cancer.

Out of 25 patients with papillary thyroid cancer, 11 patients (44\%) were without lymph node metastasis, 4 patients (16\%) had level VI cervical lymph node metastasis, and 10 patients had level II-IV cervical lymph node metastasis (40\%).

In the only patient with medullary thyroid cancer, we observed unilateral permanent laryngeal recurrent nerve palsy due to tumor nerve invasion. In one papillary thyroid cancer, we performed resection of the spinal accessory nerve (N XI) due to tumor involvement. There were relatively few postoperative complications, including a few local wound infections which resolved completely after antibiotic therapy. In 11 patients (19\%), transient hypoparathyroidism improved after calcium therapy, and hypoparathyroidism was permanent in 2 patients $(3,4 \%)$. All patients with thyroid carcinoma underwent postoperative radioactive iodine 
Table 2. Number of surgical procedures in patients with thyroid diseases confirmed by histopathological examination

\begin{tabular}{|l|c|l|}
\hline Surgical procedure & $\begin{array}{c}\text { Number of } \\
\text { patients }\end{array}$ & Histopathology \\
\hline Lobectomy & 21 & Goiter, Grave's disease, follicular adenoma \\
\hline Total thyroidectomy & 37 & $\begin{array}{l}\text { Papillary thyroid cancer, medullary thyroid cancer, } \\
\text { goiter, Grave's disease }\end{array}$ \\
\hline Paratracheal neck dissection & 12 & Papillary thyroid cancer, medullary thyroid cancer, \\
\hline Selective neck dissection & 10 & Papillary thyroid cancer, medullary thyroid cancer \\
\hline $\begin{array}{l}\text { Sternotomy and partial } \\
\text { pleurectomy }\end{array}$ & 1 & Papillary thyroid cancer \\
\hline
\end{tabular}

Table 3. Percentage of lymph node neck metastases in patients with papillary thyroid cancer

\begin{tabular}{|l|c|c|c|}
\hline \multicolumn{4}{|c|}{25 patients with papillary thyroid cancer } \\
\hline & No neck metastases & Level VI metastases & Level II-IV metastases \\
\hline Number of patients (\%) & $11(44 \%)$ & $4(16 \%)$ & $10(40 \%)$ \\
\hline
\end{tabular}

ablation. Recurrent lymph node metastasis as well as lung metastasis were found in one patient after initial treatment cervical.

\section{Discussion}

Thyroid disease is rare in the pediatric population and exhibits differences in pathophysiology, clinical presentation, and long-term outcomes. ${ }^{4}$ Thyroid cancer in people aged $<20$ years represents $1.8 \%$ of all thyroid malignancies in the United States, but the incidence appears to be increasing, and as thyroid cancer has become the eight most frequently diagnosed cancer in adolescents from 15 to 19 years old and the second most common cancer among girls. ${ }^{8}$ The most common cancer in children is papillary thyroid cancer that accounts for $>90 \%$ of cases in childhood, while follicular thyroid cancer is uncommon and medullary thyroid cancer, poorly differentiated tumors, and anaplastic thyroid carcinomas are rare in young patients. Grave's disease in children is rare, with an estimated incidence of $0.1-3.0 \%$ per 10000 children. ${ }^{9}$ Grave's disease in prepubertal children is usually more severe and more often requires radical therapy. ${ }^{10}$ In children, the first-choice treatment for Grave's disease is antithyroid drug therapy with thiamazole. Propylthiouracil (PTU) should not be prescribed in pediatric patients due to reports of PTU-induced ANCA-positive vasculitis and rapidly progressive PTU liver failure with a low chance of reversibility. ${ }^{11}$ Radioactive iodine therapy is a safe and reliable treatment but with a high risk of future hypothyroidism and thyroid cancer development or gonadal damage consequent to radiation exposure, and its use as initial therapy is therefore decreasing. ${ }^{12}$ Surgical treatment for Graves' disease is indicated in children with large goiters complicating thyroid cancer if they do not wish to receive treatment with antithyroid drugs and prefer achieving remission sooner, or if they cannot use antithyroid drugs. Unfortunately, children tend to have a higher recurrence rate and higher frequency of complications following surgery and require life-long thyroid hormone replacement. ${ }^{13}$ In our 10 -year study, we treated 23 patients with Graves's disease, with 3 among them compriseng papillary thyroid micro-carcinoma. According to the patients' indications, total thyroidectomy was performed in 11 patients, especially in children younger than 5 years, if a complete cure for hyperthyroidism is desired, in all 3 patients comprising papillary thyroid micro-carcinoma, and in patients with extremely large goiters (>80 g).

Lobectomies were performed in 12 children with Grave's disease. Nine lobectomies in our study were performed due to follicular adenoma. As stated earlier, the most common cancer in children is papillary thyroid cancer and we have to take into consideration that nodules diagnosed in children have a greater risk of malignancy compared with those in adults $(22-26 \%$ 


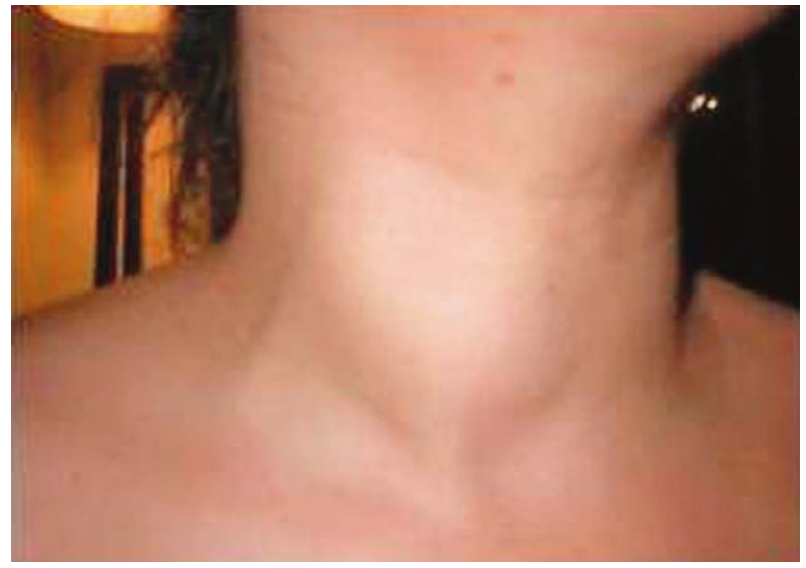

Figure 1. Photograph showing a preoperative view of a right neck swelling in a 10-year-old female patient.

versus $5-10 \%$ in most series). ${ }^{14}$ Children with papillary thyroid cancer are more likely to have regional lymph node involvement, extrathyroidal extension, and pulmonary metastasis, but despite extensive disease at clinical presentation, children are much less likely to die from disease ( $2 \%$ or less long-term cause-specific mortality) than adults (5.8-15.0\%). Many children with pulmonary metastases (30-45\%) develop stable disease following radioactive iodine therapy. ${ }^{15}$

RET/PTC rearrangements are more common in with children papillary carcinoma and do not lead to genomic instability. This might be one of the reasons for better response to radioactive iodine therapy in children and could partially explain their low mortality and rare progression. ${ }^{16}$

In our study, a total of 25 patients with papillary thyroid cancer underwent total thyroidectomy, and there were no lymph node metastases in 11 patients (44\%), whereas 4 patients (16\%) had level VI cervical lymph node metastasis and 10 patients had level II-IV cervical lymph node metastasis (40\%). Our approach to lymph node involvement recommended lymph node dissection for stage N1 patients. Prophylactic dissection on N0 patients can be recommended due to the higher rate of lymph node metastasis in children and adults. We agree with Mao et al. that papillary thyroid cancer in children has a favorable outcome as cervical lymph node metastasis is not an independent factor and can have postoperative complications following neck dissection. Patient with N0 should be treated only for central region lymph node dissection, and full neck lymph node dissection should be performed

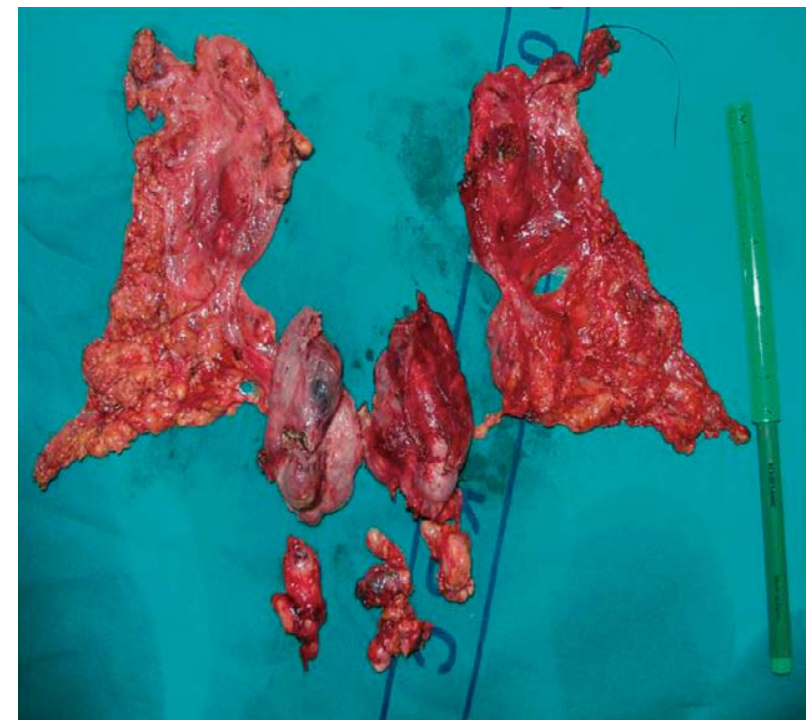

Figure 2. Photograph showing the total thyroidectomy, paratracheal dissection, and lateral neck dissection specimen of a 10-year-old female patient with papillary thyroid cancer and cytologically positive neck lymph node.

when a lateral cervical lymph node is present preoperatively or appears during postoperative follow-up. ${ }^{6,17}$

Medullary thyroid carcinoma in adults accounts for $1-2 \%$ of thyroid cancers in the United States and is even more rare in children. In the pediatric population, it is important to identify children at risk for inheriting MEN2 from a parent who refuses to disclose their specific risks to the child and the available preventative or therapeutic options. ${ }^{18}$ We had only one patient with medullary carcinoma in whom we performed total thyroidectomy, but to the nerve involvement the patient ended up with permanent unilateral recurrent nerve palsy. If we summarize the surgical approaches, in our study we have performed 58 surgeries, 37 total thyroidectomies (64\%) and 21 lobectomies (36\%), 12 paratracheal neck dissections, 10 selective neck dissections, and 1 sternotomy with partial pleural resection.

Complications in our study included transient hypoparathyroidism in $19.0 \%$ of patients and permanent hypoparathyroidism in $3.4 \%$ of patients, one permanent unilateral recurrent nerve palsy, and one unilateral resection of accessory nerve (NXI), which is comparable with results in recent publications. ${ }^{6,19,20}$ All of our cancer patients were postoperatively treated with radioiodine therapy. Only one patient had a recurrent lymph node and lung metastasis. During follow-up for all other patients, there was no sign of recurrent dis- 
ease or progression of the disease from the baseline at time of the diagnosis.

\section{Conclusion}

Thyroid surgery is important for treatment of benign thyroid diseases in children and adolescents and it is the primary treatment for thyroid cancer in children and adolescents. Well-differentiated thyroid cancer usually initially presents with locoregional lymph node metastases, which does not affect overall survival of those patients. In our group of 58 children and adolescents, total thyroidectomy and occasionally paratracheal neck dissection were recommended as the methods of choice for thyroid cancer treatment, with postoperative outcomes comparable to other reports. Lateral neck lymph node dissection is only recommended in $\mathrm{N} 1$ patients. We also found that children and adolescents who initially presented with large tumor and cervical lymph node metastasis had a favorable prognosis. All of the patients with thyroid cancer underwent postoperative radioactive iodine therapy, conventional replacement therapy, and regular follow-up. Postoperative complications from surgery for benign disease and thyroid cancer also had a similar outcome profile as those reported by different authors and demonstrated total and partial thyroidectomy was an efficient and safe procedure for treatment of thyroid disease in children and adults. Finally, according to our results, a surgeon with significant experience in adult thyroid surgery as well competence in pediatric pathology is adequate for performing thyroid surgery in children and adults.

Conflict of interest: The authors declare no conflicts of interest.

\section{References}

1. Cherella CE, Feldman HA, Hollowell M, Richman DM, Cibas ES, Smith JR i sur. Natural History and Outcomes of Cytologically Benign Thyroid Nodules in Children J Clin Endocrinol Metab. 2018; 103(9): 3557-3565.

2. Breuer C, Tuggle C, Solomon D, Sosa JA. Pediatric Thyroid Disease: When is Surgery Necessary, and Who Should be Operating on Our Children? J Clin Res Pediatr Endocrinol. 2013; 5(Suppl 1): 79-85.
3. Kusić Z, Prgomet D. Karcinom štitne i doštitne žljezde. In: Prgomet D. Tumori glave i vrata. Zagreb: Medicinska naklada. 2019.p. 262-73. Croatian

4. Francis GL, Waguespack SG, Bauer AJ, Angelos P, Benvenga S, Cerutti JM. Management Guidelines for Children with Thyroid Nodules and Differentiated Thyroid Cancer. Thyroid. 2015 Jul 1; 25(7): 716-759

5. Bas VN, Aycan Z, Cetinkaya S, Uner C, Cavusoglu YH, Arda N.Thyroid Nodules in Children and Adolescents: A Single Institution's Experience. J Pediatr Endocrinol Metab. 2012;25 (7-8):633-8.

6. Mao XC, Yu WQ, Shang JB, WANG KJ. Clinical Characteristics and Treatment of Thyroid Cancer in Children and Adolescents: A Retrospective Analysis of 83 Patients. J Zhejiang Univ Sci B. 2017;18(5):430-436

7. Prgomet D, Bilić M, Kovac L, Hutinec Z, Topić I. Locally invasive papillary thyroid cancer - our experience. Lijec Vjesn. 2012 Sep-Oct;134(9-10):266-70. Croatian

8. Wu XC, Chen VW, Steele B, Roffers S, Klotz JB, Correa CN, Carozza SE. Cancer incidence in adolescents and young adults in the United States, 1992-1997. J Adolesc Health. 2003; 32(6):405-415.

9. Lavard L, Ranlov I, Perrild H, Andersen O, Jacobsen BB. Incidence of juvenile thyrotoxicosis in Denmark, 1982-1988. A nationwide study. Eur J Endocrinol. 1994;130: 565-568.

10. Ross DS, Burch HB, Cooper DS, Greenlee MC, Laurberg P, Maia AL. American Thyroid Association Guidelines for Diagnosis and Management of Hyperthyroidism and other causes of Thyrotoxicosis. Thyroid 2016;26(10): 1343-1421.

11. Borowiec A, Labochka D, Milczarek M, Kopiec-Burdecka M, Artemniak-Wojtowicz D, Pyrzak B, Kucharska AM. Graves' disease in children in the two decades following implementation of an iodine prophylaxis programme. Cent Eur J Immunol. 2018; 43(4): 399-404.

12. Burch HB, Burman KD, Cooper DS. A 2011 Survey of Clinical Practice Patterns in the Management of Graves' Disease J Clin Endocrinol Metab. 2012;97(12):4549-58.

13. The Committee on Pharmaceutical Affairs, Japanese Society for Pediatric Endocrinology, Pediatric Thyroid Disease Committee, Japan Thyroid Association, Minamitani K, Sato H I sur. Guidelines for the treatment of childhood-onset Graves disease in Japan, 2016. Clin Pediatr Endocrinol. 2017; 26(2): 29-62.

14. Gupta A, Ly S, Castroneves LA, Frates MC, Benson CB, Feldman HA i sur. A Standardized Assessment of Thyroid Nodules in Children Confirms Higher Cancer Prevalence Than in Adults J Clin Endocrinol Metab. 2013 Aug; 98(8): 3238-3245.

15. Pawelczak M, David R, Franklin B, Kessler M, Lam L, Shah B.Outcomes of children and adolescents with well-differentiated thyroid carcinoma and pulmonary metastases following 131I treatment: a systematic review. Thyroid 2010; 20(10): 1095-1101. 
16. Monaco SE, Pantanowitz L, Khalbuss WE, Benkovich VA, Ozolek J, Nikiforova MN i sur. Cytomorphological and molecular genetic findings in pediatric thyroid fine-needle aspiration. Cancer Cytopathol 2012;120(5):342-350.

17. Prstačić R, Bumber B, Marjanović Kavanagh M, Jurlina M, Ivković I, Prgomet D. Metastasis predictors for neck sublevel IIb in papillary thyroid carcinoma [published online ahead of print, 2020 May 3]. Clin Otolaryngol. 2020;10.1111/coa. 13562. doi:10.1111/coa.13562

18. Wells SA, Asa SL, Dralle H, Elisei R, Evans DB, Gagel RF i sur. Revised American Thyroid Association Guidelines for the
Management of Medullary Thyroid Carcinoma. The American Thyroid Association Guidelines Task Force on Medullary Thyroid Carcinoma. Thyroid. 2015;25(6): 567-610.

19. Radivojević RC, Prgomet D, Markesić J, Ezgeta C. Hypocalcaemia after thyroid surgery for differentiated thyroid carcinoma: preliminary study report. Coll Antropol. 2012;36 Supp1 2:73-78.

20. Fahrner R, Übersax L, Mettler A, Berger S, Seiler CA. Paediatric thyroid surgery is safe - experiences at a tertiary surgical centre. Swiss Med Wkly. 2014;144:w13939.

Sažetak

\section{KIRURGIJA ŠTITNJAČE U DJECE I ADOLESCENATA, RETROSPEKTIVNA ANALIZA 10 GODIŠNJEG ISKUSTVA}

\section{Bilić, A. Dobrić, L. Kovač Bilic, S. Branica, I. Gugić Radojković i D. Prgomet}

Cilj. Analiza kliničkih karakterstika, kirurškog postupka, komplikacija i prognoze kod djece i adolescenata kod kojih je učinjena operacija štitnjače tijekom 10-godišnjeg razdoblja u jednoj ustanovi. Nacrt studije. Retrospektivno istraživanje. Metode. Retrospektivna analiza u razdoblju od siječnja 2011. godine do svibnja 2020. godine kod djece i adolescenata kod kojih je učinjena operacija štitnjače zbog benigne bolesti ili karcinoma štitnjače. Pokazali smo kliničke karakteristike i vrstu kirurškog zahvata tijekom liječenja benignih bolesti štitnjače i karcinoma. Rezultati. U rezultatima pokazali smo kirurške postupke tijekom deset godina u našoj ustanovi u liječenju dobroćudnih bolesti štitnjače i karcinoma štitnjače u pedijatrijskoj populaciji. Naši rezultati postoperativnih komplikacija usporedivi su sa rezultatima iz objavljenih članaka. Naglasili smo važnost postoperativnog radiojodnog liječenja i supstitucijskog liječenja kod bolesnika sa karcinomom štitnjače i naš stav vezan uz indikacije za totalnu tireoidektomiju i disekciju limfnih čvorova vrata u kirurgiji karcinoma štitnjače. Zaključak. Ova studija potvrđuje kirurgiju štitnjače kod djece i adolescenata kao sigurnu i učinkovitu ukoliko ju izvodi kirurg iskusan u operacijama štitnjače kod odraslih osoba. Za djecu i adolescente s karcinomom štitnjače naša metoda izbora je totalna tireoidektomija sa eventualnom paratrahealnom disekcijom, dok je selektivna disekcija limfnih čvorova vrata neophodna samo u slučajevima citološki pozitivnih limfnih čvorova.

Ključne riječi: tireoidektomija, dijete, adolescent 